\title{
On the measurement of the brightness of daylight
}

\section{H. W. Vogel}

To cite this article: H. W. Vogel (1897) On the measurement of the brightness of daylight, Philosophical Magazine Series 5, 44:267, 212-212, DOI: 10.1080/14786449708621057

To link to this article: http://dx.doi.org/10.1080/14786449708621057

曲 Published online: 08 May 2009.

Submit your article to this journal

Џ Article views: 3

Q View related articles $₫$ 
surfaces of feeble kathode rays may be doubled or bifurcated if the rays are strengthened. This phenomenon may be compared with the bifurcation of the interference surfaces of strong sound waves which was demonstrated by E. Mach.

Tho author contests the existence of Goldstein's deflexion as being due to an action at a distance of the kathode elements on the kathode rays.- The phenomena of deflexion may be explained partly by interference and partly by the electrostatic deflexion of kathodic rays.

Even before the discovery of the electrostatic deflexion of kathode rays, it was inferred from the theory of the author that simple feeble kathode ruys follow the maxima and minima lines of the electrostatic field, but are deflected from these lines by magnetic force. This is calculated to explain all the deflexions of the kathode rays bitherto known. Above all, this explains what at first sight is the unexpected, direction of the electrostatic deflexion of the kathode rays, as well as the deflexion of the starting-point on the kathode. The statement of E. Wiedemann that in the electrostatic deflexion only the starting-point is displaced, and that the rays continue rectilinear and perpendicular to the kathode is experimentally refuted.

The spontaneous stretching of the kathode rays is brought nearer an explanation as being a simple phenomenon of discharge. This incited experiments to compel the kathode rays to travel to the anode. Anode rays were obtained, that is kathode rays which proceed from the side of the glass, but do not remain perpendicular, but curve to the anode, and collect in a thin stem. The glass side scarcely fuoresces at all, but there is a bright fluorescent spot on the corresponding prepared anode. These anode rays are of the same nature as the katbode rays and show also corresponding deflexions.-Wiener Berichte, July 1897.

\section{ON THE MEASUREMENT OF THE BRIGHTNESS OF DAYLIGHT,}

BY H. W. VOGEL.

The author gives the following as the results of a series of observations on this subject by a method which be describes; they were made in Berlin in January of this year in very variable weather, and show the enormous differences of daylight in winter.

\begin{tabular}{|c|c|c|c|c|c|}
\hline \multirow{2}{*}{\multicolumn{6}{|c|}{ Jan. 13, 3 r.m. Strong fog ... $\quad 23$ metre-candles }} \\
\hline & 14, 2 Р.м. & Slight fog... & $79 \cdot 59$ & & \\
\hline & 15,2 Р.м. & Grey sky. Fog. . & $89 \cdot 55$ & & u \\
\hline & 16,2 P.M. & Grey sky. Fog. . & $55 \cdot 54$ & " & " \\
\hline & & & 394 & & \\
\hline
\end{tabular}

Wiedemann's Annalen, June 1897. 